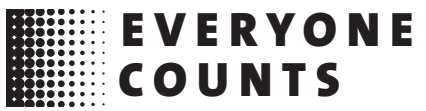




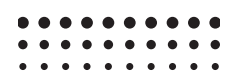

\section{MCCOURTNey Institute For Democracy}

The Pennsylvania State University's McCourtney Institute for Democracy (http://democracyinstitute.la.psu.edu) was founded in 2012 as an interdisciplinary center for research, teaching, and outreach on democracy. The institute coordinates innovative programs and projects in collaboration with the Center for American Political Responsiveness and the Center for Democratic Deliberation.

\section{Laurence and Lynne Brown Democracy Medal}

The Laurence and Lynne Brown Democracy Medal recognizes outstanding individuals, groups, and organizations that produce exceptional innovations to further democracy in the United States or around the world. In even numbered years, the medal spotlights practical innovations, such as new institutions, laws, technologies, or movements that advance the cause of democracy. Awards given in oddnumbered years highlight advances in democratic theory that enrich philosophical conceptions of democracy or empirical models of democratic behavior, institutions, or systems. 


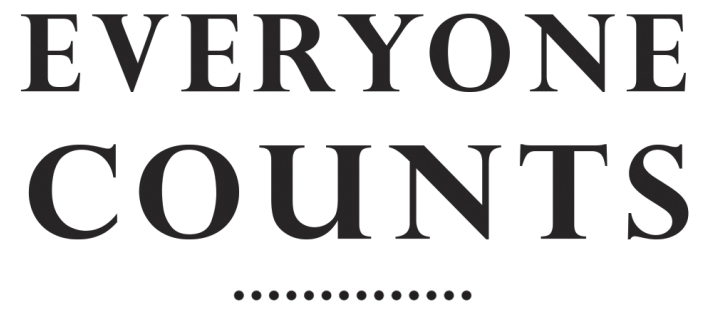

COULD

"PARIICIPATORY BUDGETING"

CHANGE DEMOCRACY?

JOSH LER NER

CORNELL SELECTS

an imprint of

Cornell University Press

Ithaca \& London 
Cornell Selects, an imprint of Cornell University Press, provides a forum for advancing provocative ideas and fresh viewpoints through outstanding digital and print publications. Longer than an article and shorter than a book, titles published under this imprint explore a diverse range of topics in a clear and concise format-one designed to appeal to any reader. Cornell Selects publications continue the Press's long tradition of supporting high quality scholarship and sharing it with the wider community, promoting a culture of broad inquiry that is a vital aspect of the mission of Cornell University.

Copyright ( 2014 by Cornell University

All rights reserved. Except for brief quotations in a review, this book, or parts thereof, must not be reproduced in any form without permission in writing from the publisher. For information, address Cornell University Press, Sage House, 512 East State Street, Ithaca, New York 14850.

First published 2014 by Cornell University Press

First printing, Cornell Paperbacks, 2014

Library of Congress Cataloging-in-Publication Data

Lerner, Josh, 1978- author.

Everyone counts : could participatory budgeting change democracy? / Josh Lerner.

pages $\mathrm{cm}$

Includes bibliographical references and index.

ISBN 978-0-8014-5665-7 (pbk. : alk. paper)

1. Budget process-United States-Citizen participation. 2. Political planning-United States-Citizen participation. 3. Local budgets-United States-Citizen participation. 4. Political participation-United States.

I. Title.

HJ2051L47 2015

352.4 ' $80973-\mathrm{dc} 23 \quad 2014033136$

Cornell University Press strives to use environmentally responsible suppliers and materials to the fullest extent possible in the publishing of its books. Such materials include vegetable-based, low-VOC inks and acid-free papers that are recycled, totally chlorine-free, or partly composed of nonwood fibers. For further information, visit our website at www.cornellpress.cornell.edu. 